

\section{The Case for a Long-Lived and Robust Yellowstone Hotspot}

Victor E. Camp, San Diego State University, Dept. of Geological Sciences, 5500 Campanile Drive, San Diego, California 92182, USA; and Ray E. Wells, U.S. Geological Survey, 2130 SW 5th Street, Portland, Oregon 97201, USA

\begin{abstract}
The Yellowstone hotspot is recognized as a whole-mantle plume with a history that extends to at least $56 \mathrm{Ma}$, as recorded by offshore volcanism on the Siletzia oceanic plateau. Siletzia accreted onto the North American plate at 51-49 Ma, followed by repositioning of the Farallon trench west of Siletzia from 48 to $45 \mathrm{Ma}$. North America overrode the hotspot, and it transitioned from the Farallon plate to the North American plate from 42 to $34 \mathrm{Ma}$. Since that time, it has been genetically associated with a series of aligned volcanic provinces associated with age-progressive events that include Oligocene high-K calc-alkaline volcanism in the Oregon backarc region with coeval adakite volcanism localized above the hot plume center; midMiocene bimodal and flood-basalt volcanism of the main-phase Columbia River Basalt Group; coeval collapse of the Nevadaplano associated with onset of Basin and Range extension and minor magmatism; and late Miocene to recent bimodal volcanism along two coeval but antithetical rhyolite migration trends - the Yellowstone-Snake River Plain hotspot track to the ENE and the Oregon High Lava Plains to the WNW.
\end{abstract}

\section{INTRODUCTION}

Most workers agree that rhyolite migration along the Yellowstone-Snake River Plain hotspot track is driven by mantle upwelling and basaltic magmatism, but they disagree on the mechanism of mantle ascent. Proponents of a shallow-mantle origin for the Yellowstone hotspot have suggested a variety of mechanisms that include rift propagation (Christiansen et al., 2002), the lateral migration of lithospheric extension (Foulger et al., 2015), and eastward mantle flow driven by sinking of the Farallon slab (Zhou et al., 2018). Other workers attribute the hotspot trend to plate motion over a deep-seated mantle plume (e.g., Hooper et al., 2007, and references therein), an origin reinforced by recent seismic tomography that resolves the Yellowstone hotspot as a high-temperature, low-density conduit that extends through the lower mantle and is sourced at the coremantle boundary (Nelson and Grand, 2018; Steinberger et al., 2019). An energetic plume is suggested by peak excess temperatures of $650-850{ }^{\circ} \mathrm{C}$ through the lower mantle (Nelson and Grand, 2018), and by an estimated range in volume flux through the upper mantle of $15 \mathrm{~m}^{3} \mathrm{~s}^{-1}$ to $31 \mathrm{~m}^{3} \mathrm{~s}^{-1}$ (Camp, 2019). Here, we examine the enduring strength and evolution of this feature by summarizing and connecting previous studies to reveal a linear progression of magmatic provinces lying along the track of a fixed Yellowstone hotspot that has been active at least since $56 \mathrm{Ma}$.

\section{PROVENANCE AND KINSHIP OF SILETZIA TO THE YELLOWSTONE HOTSPOT}

Debate on the earliest manifestation of the Yellowstone hotspot has focused on traditional models that equate the generation of continental flood-basalt provinces to melting of starting plume heads at the base of continental lithosphere (e.g., Campbell, 2005). This paradigm has led several workers to conclude that the Yellowstone starting plume head arrived at ca. $17 \mathrm{Ma}$, contemporaneous with the earliest flood-basalt eruptions of the Columbia River Basalt Group (Pierce and Morgan, 1992; Camp and Ross, 2004; Shervais and Hanan, 2008; Smith et al., 2009). Duncan (1982), however, was an early supporter of an older Yellowstone hotspot responsible for Paleocene to Eocene volcanism that created an oceanic plateau, now preserved as mafic rocks accreted to the Coast Ranges of Oregon, Washington, and Vancouver Island-the Siletzia terrane.
Although alternative models for the origin of Siletzia have been proposed, including continental margin rifting (Clowes et al., 1987; Wells et al., 1984); slab window magmatism (Babcock et al., 1992; Madsen et al., 2006); and microplate accretion (McCrory and Wilson, 2013), proximity to a hotspot seems to be required to produce the large volume of basalt. Such an origin is supported by a variety of more recent studies; for example: (1) plate reconstruction models supporting the location of a Paleocene to Eocene Yellowstone hotspot in position to produce Siletzia offshore of the northwestern U.S. (Engebretson et al., 1985; McCrory and Wilson, 2013; Wells et al., 2014; Müller et al., 2016); (2) field and geochronological data constraining the composition, age, and timing of Siletzia's accretion (Wells et al., 2014; Eddy et al., 2017); (3) volume calculations of $1.7 \times 10^{6} \mathrm{~km}^{3}$ to $2.6 \times 10^{6} \mathrm{~km}^{3}$ for the unsubducted part of the Siletzia terrane (Trehu et al., 1994; Wells et al., 2014), classifying it as a large igneous province typical of other oceanic hotspots (Bryan and Ernst, 2008); (4) elevated ${ }^{187} \mathrm{Os} /{ }^{188} \mathrm{Os}$ in Siletzia mafic lavas and ${ }^{3} \mathrm{He} /{ }^{4} \mathrm{He}$ on olivine phenocrysts, consistent with a mantle plume source (Pyle et al., 2015); (5) trace-element and Sr-Pb-Nd-Hf isotopic data delineating a heterogeneous mantle source with a plume component similar to early Columbia River Basalt Group lavas (Pyle et al., 2015; Phillips et al., 2017); and (6) mantle potential temperature calculations that are well above ambient mantle and consistent with melts derived from a hot mantle plume (Phillips et al., 2017).

Murphy (2016) suggested a still earlier period of offshore magmatism, with the Yellowstone swell entering the Farallon trench at ca. 80-75 Ma and contributing to the Laramide orogeny. The cause of the Laramide orogeny remains controversial and is not addressed here. 


\section{HOTSPOT CHRONOLOGY}

We have compiled volcanic fields previously interpreted to be related to Yellowstone hotspot magmatism across the northwestern U.S. on Figure 1, including a reconstructed Siletzia in the Eocene, in an attempt to document the magmatic progression across the forearc and through the Cascadia backarc region. Also plotted are the locations of the hotspot at $40.5 \mathrm{Ma}$ from McCrory and Wilson (2013) and a proposed hotspot track using the plate motions of Matthews et al. (2016) and assuming a fixed hotspot. The magmatic provinces are aligned with the proposed hotspot track and have a monotonic age progression similar to, but not identical to the model, which we will return to later.

Here we describe a history of progressive crustal melting manifested in the series of aligned tectonomagmatic stages in Figure $1 \mathrm{~B}$, ranging from rifting and oceanic-islandbasalt-like (OIB) lavas in the forearc, to adakitic backarc magmatism, voluminous flood basalt, and rhyolitic volcanism. These events, we suggest, record the progressive effects of a long-lived Yellowstone hotspot as it propagates from beneath oceanic lithosphere, across continental lithosphere of accreted terranes, to its current position beneath the North American craton.

\section{Volcanism and Accretion of Siletzia (ca. 56-49 Ma)} and Establishment of a New Subduction System (ca. 48-45 Ma)

Radiometric ages constrained by field mapping, global nannoplankton zones, and paleomagnetic correlations demonstrate that Siletzia was formed from 56 to $49 \mathrm{Ma}$ and

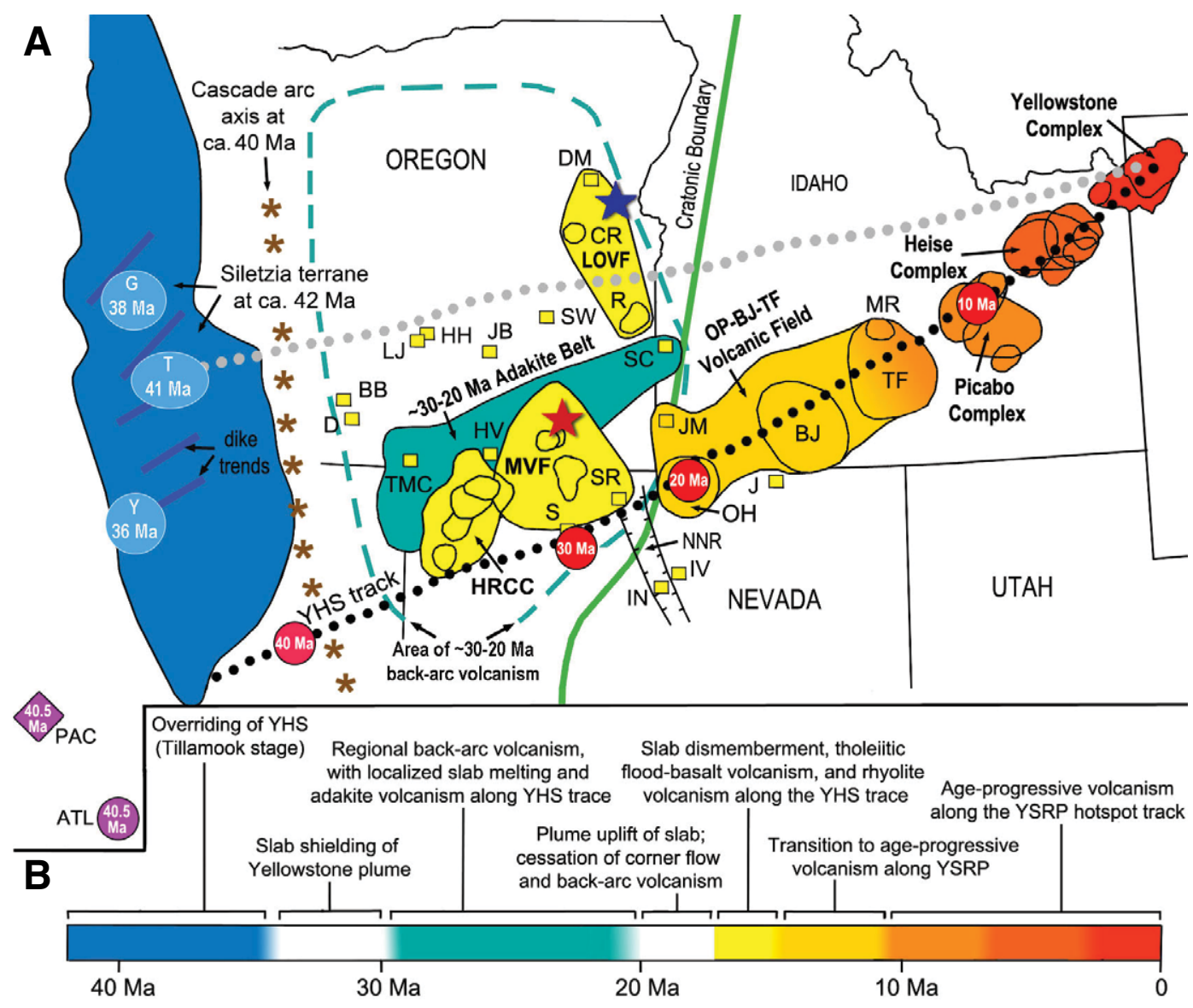

Figure 1. (A) Evolution of the Yellowstone hotspot (YHS) track relative to the North American plate. Siletzia is restored to its relative position at ca. 42 Ma when the YHS was overridden by the accreted Siletzia terrane, now part of North America. Ancestral Cascades arc location at ca. $40 \mathrm{Ma}$ is modified from Wells and McCaffrey (2013). Colored locations east of Siletzia correspond to progressive sites of crustal melting along the hotspot track since ca. $30 \mathrm{Ma}$, without removal of Basin and Range extension. Purple diamond and circle are locations of YHS with respect to N. America at $40.5 \mathrm{Ma}$ from McCrory and Wilson (2013) in Pacific (PAC) and Atlantic (ATL) hotspot frames; red dots are projected YHS locations using plate motion of Matthews et al. (2016) and assuming a fixed YHS. Black and gray dotted lines are possible YHS tracks modified from Wells et al. (2014). NNR-northern Nevada rift; YSRP-Yellowstone-Snake River Plain. Calderas, felsic volcanic fields, and lava centers from Shervais and Hanan (2008), Benson et al. (2017), and Anders et al. (2019), with colors corresponding to color-code ages in panel B. Mafic fields in the Coast Range: T-Tillamook; Y-Yachats; G-Grays River. Felsic volcanic fields: LOVF-Lake Owyhee Volcanic Field; MVF-McDermitt Volcanic Field; HRCC-Field of the High Rock Caldera Complex; OP-BJ-TF-Owyhee Plateau-Bruneau Jarbidge-Twin Falls Volcanic Field. Individual calderas shown in irregular oval polygons: MR-Magic Reservoir; OH-Owyhee-Humboldt; BJ-Bruneau-Jarbidge caldera; TF-Twin Falls caldera; R-Rooster Comb caldera; CR-caldera at Castle Rock; DM-Dooley Mountain; JM-Juniper Mountain. Contemporaneous felsic centers shown as yellow boxes: SC-Silver City; LJ-Little Juniper Mountain; HH-Horsehead Mountain; JB-Jackass Butte; SW-Swamp Creek Rhyolite; TMC-Twenty Mile Creek Rhyolite; BB-Bald Butte; D-Drum Hill; HV-Hawks Valley-Lone Mountain; S-Sleeper Rhyolite; SR-Santa Rosa-Calico; IN-Inzenhood; IV-Ivanhoe; J-Jarbidge. The two stars represent alternative sites for the plume center at 17-16 Ma, the blue-star location supported by some workers (e.g., Glen and Ponce, 2002; Shervais and Hanan, 2008; Wolff and Ramos, 2013), and the red-star location supported by others (e.g., Camp and Ross, 2004; Pierce and Morgan, 2009; Benson et al., 2017). (B) Timeline of tectonomagmatic events along the YHS track. 
accreted to North America at 51-49 Ma (Wells et al., 2014, and references therein). Accretion may have been partly contemporaneous with underplating of older parts of a greater Siletzia in the backarc region of SE Washington and adjacent Oregon (Gao et al., 2011; Schmandt and Humphreys, 2011). Trench development west of the accreted terrane was established at 48-45 Ma (Wells et al., 2014). Subduction initiation at this time is consistent with upper plate extension and post-accretion magmatism of a regional tholeiitic sill complex in the northern Oregon Coast Range (Wells et al., 2014) and with the onset of sporadic arc volcanism in the ancestral Cascades from ca. 45-36 Ma (DuBray and John, 2011).

\section{Overriding of the Yellowstone Hotspot by the North American Plate (ca. 42-34 Ma)}

At ca. $42 \mathrm{Ma}$, the leading edge of the North American plate began to override the hotspot at the site of the newly formed trench (Simpson and Cox, 1977; Wells et al., 2014). This event marks the beginning of regional margin-parallel extension, widespread dike injection, and post-accretionary hotspot magmatism of enriched mid-oceanic ridge basalt (EMORB) and OIB of the Tillamook episode from 42 to $34 \mathrm{Ma}$ (Chan et al., 2012; Parker et al., 2010; Wells et al., 2014), exemplified in the Tillamook Volcanics, Yachats basalt, and Grays River Volcanics (Fig. 1). Location of the overridden hotspot at this time therefore appears to have been in the general vicinity of southern Oregon and northern California, but perhaps slightly north of the calculated hotspot track approximated in Figure 1 (black dotted line). Welldocumented clockwise rotation and northward migration of the forearc have since moved Siletzia and the Tillamook Volcanics as much as $300 \mathrm{~km}$ to the north (Beck, 1984; Wells et al., 2014).

\section{Slab Uplift and Volcanism in the Oregon Backarc Region (ca. 30-20 Ma)}

Continued flux of the plume tail should have accumulated a significant mass of hot plume material shielded beneath the Farallon slab from 42 to $30 \mathrm{Ma}$ (e.g., Coble and Mahood, 2012). Plume arrival in the Oregon backarc generated a broad region of high-K calc-alkaline volcanism and a coeval but more localized belt of adakite volcanism from ca. 30-20 Ma (Fig. 1) (Camp et al., 2017). Mafic rocks of this episode display depletion in $\mathrm{Nb}$ and enrichment in the $\mathrm{H}_{2} \mathrm{O}$ soluble elements $\mathrm{Rb}, \mathrm{Ba}, \mathrm{K}$, and $\mathrm{Pb}$, a chemical signature that requires melting of a hydrated mantle source. Camp et al. (2017) attribute source enrichment to plume-induced uplift and heating of the slab resulting in the liberation of $\mathrm{H}_{2} \mathrm{O}$ into the overlying mantle wedge, thus lowering solidus temperatures and promoting partial melting of hydrated mantle beneath the Oregon backarc from 30 to $20 \mathrm{Ma}$ (Fig. 1).

Thermomechanical erosion of the Farallon slab is suggested by the ENE-trending belt of 30-to-20 Ma adakite, thought to be derived from slab melting of oceanic crust (Fig. 1). The low solidus temperature of this mafic source makes it highly susceptible to thermal erosion and melt generation above the feeding plume tail, where maximum temperatures are maintained (Campbell, 2005). The adakite belt lies parallel to plate motion and has been described as an older extension of the Yellowstone-Snake River Plain hotspot track to the east (Camp et al., 2017).

\section{Volcanic Hiatus in the Backarc Region (ca. $20 \mathrm{Ma}$ to $17 \mathrm{Ma}$ )}

Calc-alkaline and adakite volcanism in the backarc region waned dramatically at $22 \mathrm{Ma}$ and ceased at $20 \mathrm{Ma}$. Thus began a 3-5-m.y. volcanic hiatus that is well established in eastern Oregon and northernmost Nevada (Coble and Mahood, 2012, and references therein). Coble and Mahood (2012) attribute this hiatus to continued plume uplift of the Farallon slab leading to the cessation of corner flow in the overlying mantle wedge. The hiatus separates two distinct magmatic perturbations in the backarc region: (1) the older period of calc-alkaline magmatism from 30 to $20 \mathrm{Ma}$, where mafic rocks were derived from a wet mantle source; and (2) a younger period of tholeiitic flood-basalt to bimodal magmatism from 17 to $15 \mathrm{Ma}$, where mafic rocks were derived from a dry mantle source.

\section{Slab Rupture and Tholeiitic Flood Basalt to Bimodal Volcanism (ca. 17-15 Ma)}

The volcanic hiatus ended at ca. $17 \mathrm{Ma}$ with fissure eruptions of the voluminous main-phase lavas of the Columbia River Basalt Group, all of which share a plume-like component based on trace-element and isotopic data (e.g., Wolff and Ramos, 2013). The main phase generated $93 \%\left(194,000 \mathrm{~km}^{3}\right)$ of the Columbia River Basalt Group volume in ca. 600,000 years (Kasbohm and Schoene, 2018). This narrow age-range overlaps with the age of bimodal eruptions along the northern Nevada rift from 16.5 to $15.0 \mathrm{Ma}$ (John et al., 2000) and with high-volume rhyolite eruptions in SE Oregon and NW Nevada from 16.5 to $15.5 \mathrm{Ma}$ (Fig. 1) (Coble and Mahood, 2016; Benson et al., 2017). The oldest rhyolites at 16.5-16.1 Ma (i.e., HRCC, MVF, SR, S, HV, and J on Fig. 1) and the most voluminous rhyolite fields $\left(\sim 5000 \mathrm{~km}^{3}\right.$; HRCC and MVF on Fig. 1) lie in a narrow belt adjacent and parallel to the projected Yellowstone hotspot track (Fig. 1). In total, this 17-15 Ma event of flood basalt and bimodal volcanism produced a $\mathrm{N}-\mathrm{S}$ system of coeval dike swarms, rhyolitic calderas and large, mid-crustal keel dikes expressed as linear aeromagnetic anomalies (Glen and Ponce, 2002) that extend from eastern Washington to central Nevada and perhaps into southern Nevada (Pierce and Morgan, 1992), the Nevada-Columbia Basin Magmatic Belt (Fig. 2) of Camp et al. (2015).

Liu and Stegman (2012) attribute the Nevada-Columbia Basin Magmatic Belt to slab tearing along a N-S hinge line beneath eastern Oregon, followed by upwelling and melting of subslab asthenosphere. Other workers prefer a modification of this process with slab rupture near the eastern hinge of plume-driven uplift (Coble and Mahood, 2012; Camp et al., 2015), tearing $\mathrm{N}-\mathrm{S}$ in much the same manner as envisioned by Liu and Stegman (2012). Extension of the Nevada-Columbia Basin Magmatic Belt into NE Oregon and SE Washington (Fig. 2) may have also been augmented by the northward deflection of spreading plume material against the thick cratonic boundary (e.g., Sleep, 1996; Camp, 1995), and/or by the long-distance lateral migration of dikes from centralized magma chambers farther south (Wolff and Ramos, 2013).

Slab dismemberment beneath eastern Oregon is consistent with seismic studies that resolve a truncated subducting plate that terminates at $\sim 300 \mathrm{~km}$ depth, with fast anomalies farther east interpreted as Farallon slab remnants (e.g., Obrebski et al., 2010). The intervening slab hole lies directly beneath the axial trend of the older (30-20 Ma) adakite hotspot track and the younger continuation of the Yellowstone-Snake River Plain hotspot track (e.g., figure $3 f$ of Obrebski et al., 2010).

\section{Plume Relationship to Regional Tectonics (17-15 Ma)}

The events at 17-15 Ma occurred during a time when western North America was evolving from a convergent to a transform 


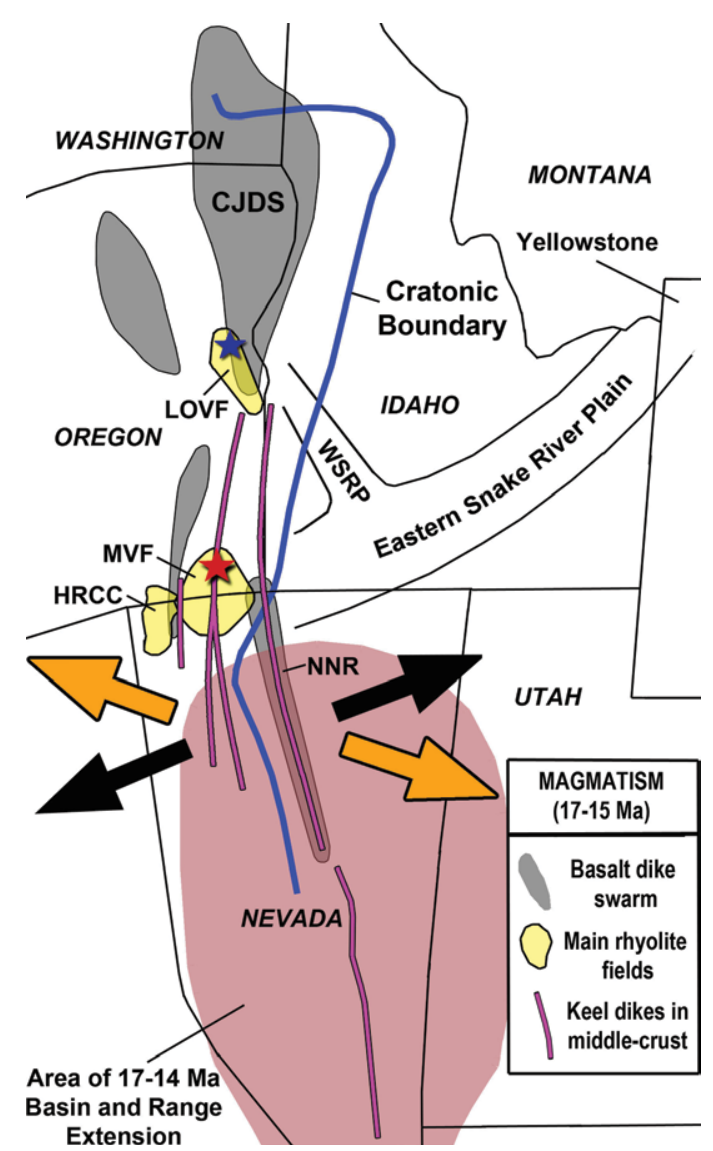

Figure 2. Palinspastic reconstruction of bimodal volcanism along the NevadaColumbia Basin magmatic belt from ca. 17-15 Ma, with southernmost extension based solely on aeromagnetic data. See Figure 1 for definition of red and blue stars and volcanic fields HRCC, MVF, LOVF, and NNR. Orange arrows depict the orientation of mid-Miocene Basinand-Range extension; black arrows depict the overall dilation direction of coeval mid-Miocene dikes. CJDS-Chief Joseph dike swarm, where $85 \%$ of the Columbia River Basalt Group volume erupted. Area of 17-14 Ma extension from Colgan and Henry (2009). WSRPWestern Snake River Plain.

setting. Basin-and-Range extension began at 17-16 Ma (Colgan and Henry, 2009) when torsional stress was fully imposed on the continental interior due to plate-boundary tectonics (Dickinson, 1997).

Could the initiation of continental extension at 17-16 Ma be the root cause of coeval flood-basalt and related magmatism in the Nevada-Columbia Basin Magmatic Belt (e.g., Dickinson, 1997)? Such a scenario conflicts with two observations: (1) the greatest eruptive volume was in the area of least extension (e.g., the Chief Joseph dike swarm; CJDS on Fig. 2), while the smallest eruptive volume was in the Basin-and-Range region of far greater extension (e.g., the NNR on Fig. 2); and (2) early crustal extension in the northern and central Basin-and-Range generated structural elements with NNE trends, but coeval magmatic intrusion along the Nevada-Columbia Basin Magmatic Belt generated dikes with NNW trends, a $45^{\circ}$ difference (e.g., Colgan, 2013). Camp et al. (2015) and Morriss et al. (2020) attributed the source of these magmatic trends instead to a bottom-up process of forceful dike injection due to high magma overpressure unrelated to regional stress.
Ma. Slab rupture and adiabatic rise of this accumulated mantle generated bimodal eruptions of flood basalt and rhyolite from 17 to $15 \mathrm{Ma}$, the latter driven by basalt injection and melting of fertile crust near the center of the Nevada-Columbia Basin Magmatic Belt (e.g., Coble and Mahood, 2016; Benson et al., 2017).

Silicic volcanism remained dispersed until ca. $14 \mathrm{Ma}$ when rhyolitic eruptions became more focused along the Yellowstone-Snake River Plain in SW Idaho (Fig. 1). Here, bimodal eruptions from ca. 14 Ma to $10 \mathrm{Ma}$ are thought to be associated with the transition from volcanism above the broad accumulation of plume material to volcanism above the narrow plume tail, as the former was overridden by continental lithosphere of the North American craton (Pierce and Morgan, 1992; Shervais and Hanan, 2008). A systematic ENE progression of younger inception ages for rhyolite fields in the central Snake River Plain began between 12.5$10.8 \mathrm{Ma}$, with the plume tail establishing a well-defined hotspot-migration trend by ca. $10 \mathrm{Ma}$ (Pierce and Morgan, 1992, 2009).

\section{Coeval Rhyolite Migrations along Opposing Trends (10 Ma to Recent)}

Anders et al. (2019) calculated a migration rate of $2.27 \pm 0.21 \mathrm{~cm} / \mathrm{yr}$ along the Yellowstone-Snake River Plain trend since $10.41 \mathrm{Ma}$, which is close to independent estimates of plate motion along the same ENE trend (Fig. 3). This is consistent with a fixed Yellowstone hotspot over this timeframe, similar to the classic Hawaiian-type model of plate motion above a stationary plume tail.

Contemporaneous silicic migration since 10 Ma occurs across the Oregon High Lava Plains from SE Oregon toward the Newberry volcano east of the Oregon Cascades arc (e.g., Jordan et al., 2004). This WNW trend (Fig. 3) is antithetical to the YellowstoneSnake River Plain trend and is often cited as evidence against a plume origin (e.g., Christiansen et al., 2002; Foulger et al., 2015). Several workers attribute the High Lava Plains trend to mantle upwelling associated with slab rollback (e.g., Long et al., 2009; Ford et al., 2013), but this may be difficult to reconcile with evolving seismic data that reveal a shortened and highly fragmented slab in this region (Long, 2016). Slab fragmentation is described by Hawley and Allen (2019) as a propagating tear responsible for westward mantle flow beneath the High Lava Plains trend. Following Jordan et al. 


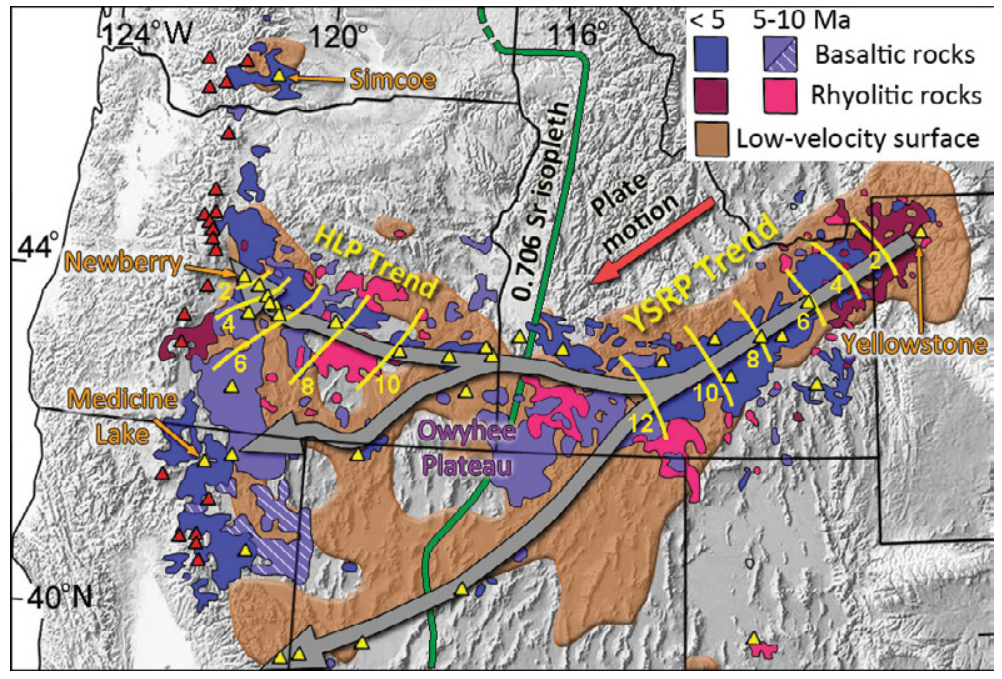

Figure 3. Volcanic rocks younger than $10 \mathrm{Ma}$ superimposed above sublithospheric low-velocity surface of Wagner et al. (2010). Yellow lines are isochrons for rhyolite volcanism along the Yellowstone-Snake River Plain (YSRP) and High Lava Plains (HLP). Red triangles are Holocene volcanoes of the high Cascades; yellow triangles are areas of Quaternary volcanism in the Cascadia backarc region largely corresponding with seismic low-velocity channels of plume-modified mantle flow; channel axes approximated by gray arrows. Modified from Camp (2019).

(2004), Wells and McCaffrey (2013) calculated that the High Lava Plains progression migrated westward due to mantle counterflow at the slab subduction rate until it hit the slab at $5 \mathrm{Ma}$, when it slowed to the rollback rate, driven by forearc rotation. Camp (2019) described an alternative model of westward mantle flow driven by plume flux sheared in the direction of plate motion but augmented by rapid, thermally driven buoyancy flow across the cratonic boundary of North America. According to this model, Mioceneto-recent flow of plume-modified mantle generated a broad seismic low-velocity feature described by Wagner et al. (2010), which emanates from the Yellowstone hotspot and currently underlies the Snake River Plain and High Lava Plains volcanic rocks (Fig. 3). Quaternary flow at the top of this larger feature is evident in the identification of fingerlike channels of low seismic velocity at $75 \mathrm{~km}$ depth coincident with the dispersed alignment of young volcanic centers that extend from Yellowstone to the Cascades volcanic arc (Fig. 3).

\section{Magmatic Timing versus Plate Motions}

The magmatic progression nicely follows a linear trend between the predicted Yellowstone hotspot location at $40 \mathrm{Ma}$ and its present location (Fig. 1), but magmatism between 17 and 10 Ma lags 5-10 m.y. behind the predicted appearance from the fixed hotspot track. Accounting for Basin-Range extension could reduce some, but not all, of the misfit, and the time required for the Yellowstone hotspot to escape from beneath the slab curtain also could have contributed substantially to the delay. Jordan et al. (2004) suggested an additional mechanism, where plume material was deflected west of the hotspot location after ca. $20 \mathrm{Ma}$ as it rose obliquely against the base of shallowing lithosphere, ponding beneath thinner lithosphere west of the cratonic boundary. Finally, the uncertainties in the plate models and the possibility of Cenozoic true polar wander (Woodworth and Gordon, 2018) may be significant at this scale. Although formal uncertainties are not typically provided, the differences in the $40 \pm$ Ma position of the Yellowstone hotspot may give some idea of the variability in models.

\section{SUMMARY}

The combined evidence suggests that Yellowstone plume-lithosphere interaction may have been more significant than previously thought, contributing to a linear ageprogression of tectonomagmatic events and aligned volcanic provinces since $56 \mathrm{Ma}$. These include: (1) late Paleocene to Eocene volcanism and accretion of the Siletzia oceanic terrane; (2) rifting and OIB-like forearc magmatism at $42 \mathrm{Ma}$ following establishment of a new trench west of the accreted terrane as the leading edge of North America overrode the Yellowstone hotspot; (3) Oligocene eruption of high-K calc-alkaline lavas in the
Oregon backarc region resulting from plume uplift and heating of the Farallon slab, leading to volatile release and melting of the mantle wedge; (4) coeval Oligocene adakite volcanism during thermomechanical erosion of the slab and melting of oceanic crust; (5) slab rupture resulting in adiabatic rise and melting of a plume source component found in Miocene tholeiitic flood basalts of the Columbia River Basalt Group and the Nevada-Columbia Basin Magmatic Belt; (6) active mantle upwelling beneath the Nevadaplano that may have aided in plateau collapse and Miocene initiation of Basin-and-Range extension; (7) Miocene-to-recent bimodal volcanism and rhyolite migration along the Yellowstone-Snake River Plain hotspot track to the ENE; and (8) westward sublithospheric flow of plume-modified mantle, resulting in Miocene-to-recent bimodal volcanism with rhyolite migration along the Oregon High Lava Plains to the WNW.

\section{ACKNOWLEDGMENTS}

We thank Joe Colgan for constructive comments on an earlier draft of the manuscript, two anonymous journal reviewers for their helpful comments, and Mihai Ducea for editorial handling.

\section{REFERENCES CITED}

Anders, M.H., DiVenere, V.J., Hemming, S.R., and Gombiner, J., 2019, ${ }^{40} \mathrm{Ar} /{ }^{39} \mathrm{Ar}$ and paleomagnetic constraints on the age and areal extent of the Picabo volcanic field: Implications for the YHS: Geosphere, v. 15 , p. 716-735, https://doi.org/10.1130/ GES01589.1.

Babcock, R.S., Burmester, R.F., Engebretson, D.C., Warnock, A., and Clark, K.P., 1992, A rifted margin origin for the Crescent basalts and related rocks in the northern Coast Range volcanic province, Washington and British Columbia: Journal of Geophysical Research, Solid Earth, v. 97, B5, p. 6799-6821, https://doi.org/10.1029/91JB02926.

Beck, M.E., Jr., 1984, Has the Washington-Oregon coast range moved northward?: Geology, v. 12, no. 12 , p. 737-740, https://doi.org/10.1130/ 0091-7613(1984)12<737:HTWCRM>2.0.CO;2.

Benson, T.R., Mahood, G.A., and Grove, M., 2017, Geology and ${ }^{40} \mathrm{Ar} /{ }^{39} \mathrm{Ar}$ geochronology of the middle Miocene McDermitt volcanic field, Oregon and Nevada: Silicic volcanism associated with the propagating flood basalt dikes at initiation of the Yellowstone hotspot: Geological Society of America Bulletin, v. 129, p. 1027-1051 https://doi.org/10.1130/B31642.1.

Bryan, S.E., and Ernst, R.E., 2008, Revised definition of large igneous provinces (LIPs): EarthScience Reviews, v. 86, no. 1-4, p. 175-202, https://doi.org/10.1016/j.earscirev.2007.08.008.

Camp, V.E., 1995, Mid-Miocene propagation of the Yellowstone mantle plume head beneath the Columbia River Basalt source region: Geology, v. 23, p. 435-438, https://doi.org/10.1130/0091 -7613(1995)023<0435:MMPOTY>2.3.CO;2.

Camp, V.E., 2019, Plume-modified mantle flow in the northern Basin and Range and southern Cas- 
cadia back-arc region since $12 \mathrm{Ma}$ : Geology, v. 47, p. 695-699, https://doi.org/10.1130/G46144.1.

Camp, V.E., and Ross, M.E., 2004, Mantle dynamics and genesis of mafic magmatism in the intermontane Pacific Northwest: Journal of Geophysical Research, v. 109, B08204, https://doi.org/ 10.1029/2003JB002838.

Camp, V.E., Pierce, K.L., and Morgan, L.A., 2015, Yellowstone plume trigger for Basin and Range extension and coeval emplacement of the Nevada-Columbia Basin magmatic belt: Geosphere, v. 11, no. 2, p. 203-225, https://doi.org/ 10.1130/GES01051.1.

Camp, V.E., Ross, M.E., Duncan, R.A., and Kimbrough, D.L., 2017, Uplift, rupture, and rollback of the Farallon slab reflected in volcanic perturbations along the Yellowstone adakite hot spot track: Journal of Geophysical Research, v. 122, p. 70097041, https://doi.org/10.1002/2017JB014517.

Campbell, I.H., 2005, Large igneous provinces and the mantle plume hypothesis: Elements, v. 1, p. 265-269, https://doi.org/10.2113/gselements 1.5.265.

Chan, D.F., Tepper, J.H., and Nelson, B.K., 2012, Petrology of the Grays River volcanics, southwestern Washington: Plume-influenced slab window magmatism in the Cascadia forearc: Geological Society of America Bulletin, v. 124, p. 1324-1338, https://doi.org/10.1130/B30576.1.

Christiansen, R.L., Foulger, G.R., and Evans, J.R., 2002, Upper-mantle origin of the YHS: Geological Society of America Bulletin, v. 114, p. 12451256, https://doi.org/10.1130/0016-7606(2002)114 $<1245$ :UMOOTY>2.0.CO;2.

Clowes, R.M., Brandon, M.T., Green, A.G., Yorath, C.J., Brown, A.S., Kanasewich, E.R., and Spencer, C., 1987, LITHOPROBE-Southern Vancouver Island: Cenozoic subduction complex imaged by deep seismic reflections: Canadian Journal of Earth Sciences, v. 24, no. 1, p. 31-51, https://doi.org/10.1139/e87-004.

Coble, M.A., and Mahood, G.A., 2012, Location of initial impingement of the Yellowstone plume defined by widespread silicic volcanism contemporaneous with Columbia River Basalts: Geology, v. 40, p. 655-658, https://doi.org/10.1130/G32692.1.

Coble, M.A., and Mahood, G.A., 2016, Geology of the High Rock caldera complex, northwest Nevada, and implications for intense rhyolitic volcanism associated with flood basalt magmatism and the initiation of the Snake River Plain-Yellowstone trend: Geosphere, v. 12, no. 1, p. 58-113, https://doi .org/10.1130/GES01162.1.

Colgan, J.P., 2013, Reappraisal of the relationship between the northern Nevada rift and Miocene extension in the northern Basin and Range Province: Geology, v. 41, p. 211-214, https://doi.org/ 10.1130/G33512.1.

Colgan, J.P., and Henry, C.D., 2009, Rapid middle Miocene collapse of the Mesozoic orogenic plateau in north-central Nevada: International Geology Review, v. 51, p. 920-961, https://doi.org/ 10.1080/00206810903056731.

Dickinson, W.R., 1997, Tectonic implications of Cenozoic volcanism in coastal California: Geological Society of America Bulletin, v. 109, p. 936-954, https://doi.org/10.1130/0016-7606 (1997) $109<0936$ :OTIOCV>2.3.CO;2.

du Bray, E.A., and John, D.A., 2011, Petrologic, tectonic, and metallogenic evolution of the Ancestral Cascades magmatic arc, Washington, Oregon, and northern California: Geosphere, v. 7, p. 11021133, https://doi.org/10.1130/GES00669.1.

Duncan, R.A., 1982, A captured island chain in the coast range of Oregon and Washington: Journal of Geophysical Research, v. 87, p. 10,827-10,837, https://doi.org/10.1029/JB087iB13p10827.

Eddy, M.P., Clark, K.P., and Polenz, M., 2017, Age and volcanic stratigraphy of the Eocene Siletzia oceanic plateau in Washington and on Vancouver Island: Lithosphere, v. 9, p. 652-664, https:// doi.org/10.1130/L650.1.

Engebretson, D.C., Cox, A., and Gordon, R.G., 1985, Relative motions between oceanic and continental plates in the Pacific basin: Geological Society of America Special Paper 206, 59 p., https://doi.org/10.1130/SPE206-p1.

Ford, M.T., Grunder, A.L., and Duncan, R.A., 2013, Bimodal volcanism of the High Lava Plains and northwestern Basin and Range of Oregon: Distribution and tectonic implications of age-progressive rhyolites: Geochemistry, Geophysics, Geosystems, v. 14, p. 2836-2857, https://doi.org/ 10.1002 /ggge.20175.

Foulger, G.R., Christiansen, R.L., and Anderson, D.L., 2015, The Yellowstone "hot spot" track results from migrating basin-range extension, in Foulger, G.R., Lustrino, M., and King, S.D., eds., The Interdisciplinary Earth: A Volume in Honor of Don L. Anderson: Geological Society of America Special Paper 514 and American Geophysical Union Special Publication 71, p. 215238, https://doi.org/10.1130/2015.2514(14).

Gao, H., Humphreys, E.D., Yao, H., and van der Hilst, R.D., 2011, Crust and lithosphere structure of the northwestern US with ambient noise tomography: Terrane accretion and Cascade arc development: Earth and Planetary Science Letters, v. 304, p. 202-211, https://doi.org/10.1016/ j.epsl.2011.01.033.

Glen, J.M.G., and Ponce, D.A., 2002, Large-scale fractures related to inception of the YHS: Geology, v. 30, p. 647-650, https://doi.org/10.1130/ 0091-7613(2002)030<0647:LSFRTI>2.0.CO;2.

Hawley, W.B., and Allen, R.M., 2019, The fragmented death of the Farallon plate: Geophysical Research Letters, v. 46, p. 7386-7394, https:// doi.org/10.1029/2019GL083437.

Hooper, P.R., Camp, V.E., Reidel, S.P., and Ross, M.E., 2007, The origin of the Columbia River flood basalt province: Plume versus nonplume models, in Foulger, G.R., and Jurdy, D.M., eds., Plates, Plumes, and Planetary Processes: Geological Society of America Special Paper 430, p. 635-668, https://doi.org/10.1130/2007.2430(30).

John, D.A., Wallace, A.R., Ponce, D.A., Fleck, R., and Conrad, J.E., 2000, New perspectives on the geology and origin of the Northern Nevada rift, in Cluer, J.K., Price, J.G., Struhsacker, E.M., Hardyman, R.F., and Morris, C.L., eds., Geology and Ore Deposits 2000: The Great Basin and Beyond: Proceedings of the Geological Society of Nevada Symposium, p. 127-154.

Jordan, B.J., Grunder, A.L., Duncan, R., and Deino, A., 2004, Geochronology of age progressive volcanism of the Oregon High Lava Plains: Implications for the plume interpretation of Yellowstone: Journal of Geophysical Research, v. 109, B10202, https://doi.org/10.1029/2003JB002776.

Kasbohm, J., and Schoene, B., 2018, Rapid eruption of the Columbia River flood basalt and correlation with mid-Miocene climate optimum: Sci- ence Advances, v. 4, no. 9, https://doi.org/10.1126/ sciadv.aat 8223

Liu, L., and Stegman, D.R., 2012, Origin of Columbia River flood basalt controlled by propagating rupture of the Farallon slab: Nature, v. 482, p. 386-389, https://doi.org/10.1038/nature10749.

Long, M.D., 2016, The Cascadia paradox: Mantle flow and slab fragmentation in the Cascadia subduction system: Journal of Geodynamics, v. 102, p. 151170, https://doi.org/10.1016/j.jog.2016.09.006.

Long, M.D., Gao, H.K.A., Wagner, L.S., Fouch, M.J., James, D.E., and Humphreys, E., 2009, Shear wave splitting and the pattern of mantle flow beneath eastern Oregon: Earth and Planetary Science Letters, v. 288, p. 359-369, https:// doi.org/10.1016/j.eps1.2009.09.039.

Madsen, J.K., Thorkelson, D.J., Friedman, R.M., and Marshall, D.D., 2006, Cenozoic to Recent plate configurations in the Pacific Basin: Ridge subduction and slab window magmatism in western North America: Geosphere, v. 2, no. 1, p. 11-34, https://doi.org/10.1130/GES00020.1.

Matthews, K.J., Maloney, K.T., Zahirovic, S., Williams, S.E., Seton, M., and Mueller, R.D., 2016, Global plate boundary evolution and kinematics since the late Paleozoic: Global and Planetary Change, v. 146, p. 226-250, https://doi.org/10.1016/ j.gloplacha.2016.10.002.

McCrory, P.A., and Wilson, D.S., 2013, A kinematic model for the formation of the Siletz-Crescent forearc terrane by capture of coherent fragments of the Farallon and Resurrection plates: Tectonics, v. 32, p. 718-736, https://doi.org/10.1002/ tect. 20045.

Morriss, M.C., Karlstrom, L., Nashoolds, M.W.M., and Wolff, J.A., 2020, The Chief Joseph dike swarm of the Columbia River Flood Basalts, and the legacy data set of William H. Taubeneck: Geosphere, v. 16, https://doi.org/10.1130/GES02173.1.

Müller, R.D., Seton, M., Zahirovic, S., Williams, S.E., Matthews, K.J., Wright, N.M., Shephard, G.E., Maloney, K.T., Barnett-Moore, N., Hosseinpour, M., and Bower, D.J., 2016, Ocean basin evolution and global-scale plate reorganization events since Pangea breakup: Annual Review of Earth and Planetary Sciences, v. 44, p. 107-138, https:// doi.org/10.1146/annurev-earth-060115-012211.

Murphy, J.B., 2016, The role of the ancestral Yellowstone plume in the tectonic evolution of the western United States: Geoscience Canada, v. 43, p. 231250, https://doi.org/10.12789/geocanj.2016.43.105.

Nelson, P.L., and Grand, S.P., 2018, Lower-mantle plume beneath the Yellowstone hotspot revealed by core waves: Nature Geoscience, v. 11, no. 4, p. 280 284, https://doi.org/10.1038/s41561-018-0075-y.

Obrebski, M., Allen, R.M., Xue, M., and Hung, S.-H., 2010, Slab-plume interaction beneath the Pacific Northwest: Geophysical Research Letters, v. 37, L14305, https://doi.org/10.1029/2010GL043489.

Parker, D.F., Hodges, F.N., Perry, A., Mitchener, M.E., Barnes, M.A., and Ren, M., 2010, Geochemistry and petrology of late Eocene Cascade Head and Yachats Basalt and alkalic intrusions of the central Oregon Coast Range, USA: Journal of Volcanology and Geothermal Research, v. 198, no. 3-4, p. 311-324, https://doi.org/ 10.1016/j.jvolgeores.2010.09.016.

Phillips, B.A., Kerr, A.C., Mullen, E.K., and Weis, D., 2017, Oceanic mafic magmatism in the Siletz terrane, NW North America: Fragments of an Eo- 
cene oceanic plateau: Lithos, v. 274-275, p. 291303, https://doi.org/10.1016/j.lithos.2017.01.005.

Pierce, K.L., and Morgan, L.A., 1992, The track of the Yellowstone hot spot: Volcanism, faulting, and uplift, in Link, P.K., ed., Regional Geology of Eastern Idaho and Western Wyoming: Geological Society of America Memoir 179, p. 1-54, https://doi.org/10.1130/MEM179-p1.

Pierce, K.L., and Morgan, L.A., 2009, Is the track of the YHS driven by a deep mantle plume?Review of volcanism, faulting and uplift in light of new data: Journal of Volcanology and Geothermal Research, v. 188, p. 1-25, https://doi.org/ 10.1016/j.jvolgeores.2009.07.009.

Pierce, K.L., Morgan, L.A., and Saltus, R.W., 2002 , Yellowstone plume head: Postulated tectonic relations to the Vancouver slab, continental boundaries, and climate, in Bonnichsen, B., White, C.M., and McCurry, M., eds., Tectonic and Magmatic Evolution of the Snake River Plain Volcanic Province: Idaho Geological Survey Bulletin 30, p. 5-33.

Pyle, D.G., Duncan, R.A., Wells, R.E., Graham, D.W., Hanan, B.B., Harrison, B.K., and Haileab, B., 2015, Longevity of YHS volcanism: Isotopic evidence linking the Siletzia LIP (56 Ma) and early Columbia River Basalt Group (17 Ma) to mantle sources: American Geophysical Union Fall Meeting, Abstract V31E-3060.

Schmandt, B., and Humphreys, E.D., 2011, Seismically imaged relict slab from the $55 \mathrm{Ma}$ Siletzia accretion to the northwest United States: Geology, v. 39, p. 175-178, https://doi.org/10.1130/ G31558.1.

Shervais, J.W., and Hanan, B.B., 2008, Lithospheric topography, tilted plumes, and the track of the Snake River-Yellowstone hot spot: Tectonics, v. 27, TC5004, https://doi.org/10.1029/ 2007 TC002181.
Simpson, R.W., and Cox, A., 1977, Paleomagnetic evidence for tectonic rotation of the Oregon Coast Range: Geology, v. 5, p. 585-589, https:// doi.org/10.1130/0091-7613(1977)5<585:PEFTRO $>2.0 . \mathrm{CO} ; 2$.

Sleep, N.H., 1996, Lateral flow of hot plume material ponded at sublithospheric depths: Journal of Geophysical Research, v. 101, p. 28,065-28,083, https://doi.org/10.1029/96JB02463.

Smith, R.B., Jordan, M., Steinberger, B., Puskas, C.M., Farrell, J., Waite, G.P., Husen, S., Wu-Lung, C., and O'Connell, R., 2009, Geodynamics of the Yellowstone hotspot and mantle plume: Seismic and GPS imaging, kinematics, and mantle flow: Journal of Volcanology and Geothermal Research, v. 188 , p. 26-56, https://doi.org/10.1016/ j.jvolgeores.2009.08.020.

Steinberger, B., Nelson, P.L., Grand, S.P., and Wang, W., 2019, Yellowstone plume conduit tilt caused by large-scale mantle flow: Geochemistry, Geophysics, Geosystems, v. 20, https://doi.org/10.1029/ 2019GC008490.

Trehu, A.M., Asudeh, I., Brocher, T.M., Luetgert, J.H., Mooney, W.D., Nabelek, J.L., and Nakamura, Y., 1994, Crustal architecture of the Cascadia forearc: Science, v. 266, p. 237-243, https:// doi.org/10.1126/science.266.5183.237.

Wagner, L., Forsyth, D.W., Fouch, M.J., and James, D.E., 2010, Detailed three-dimensional shear wave velocity structure of the northwestern United States from Rayleigh wave tomography: Earth and Planetary Science Letters, v. 299, p. 273-284, https://doi.org/10.1016/j.eps1.2010.09.005.

Wells, R.E., and McCaffrey, R., 2013, Steady rotation of the Cascade arc: Geology, v. 41, p. $1027-$ 1030, https://doi.org/10.1130/G34514.1.

Wells, R.E., Engebretson, D.C., Snavely, P.D., Jr., and Coe, R.S., 1984, Cenozoic plate motions and the volcano-tectonic evolution of western Oregon and Washington: Tectonics, v. 3, no. 2, p. 275294, https://doi.org/10.1029/TC003i002p00275.

Wells, R.E., Bukry, D., Friedman, R., Pyle, D., Duncan, R.A., Haeussler, P., and Wooden, J., 2014, Geologic history of Siletzia, a large igneous province in the Oregon and Washington Coast Range: Correlation to the geomagnetic polarity time scale and implications for a longlived Yellowstone hotspot: Geosphere, v. 10, p. 692-719, https://doi.org/10.1130/GES01018.1.

Wolff, J.A., and Ramos, F.C., 2013, Source materials for the main phase of the Columbia River Basalt Group: Geochemical evidence and implications for magma storage and transport, in Reidel, S.P., Camp, V.E., Ross, M.E., Wolff, J.A., Martin, B.S., Tolan, T.L., and Wells, R.E., eds., The Columbia River Flood Basalt Province: Geological Society of America Special Paper 497, p. 273-291, https:// doi.org/10.1130/2013.2497(11).

Woodworth, D., and Gordon, R.G., 2018, Paleolatitude of the Hawaiian hot spot since $48 \mathrm{Ma}$ : Evidence for a mid-Cenozoic true polar stillstand followed by late Cenozoic true polar wander coincident with Northern Hemisphere glaciation: Geophysical Research Letters, v. 45, no. 21 , p. 11,632-11,640, https://doi.org/10.1029/ 2018GL080787.

Zhou, Q., Liu, L., and Hu, J., 2018, Western US volcanism due to intruding oceanic mantle driven by ancient Farallon slabs: Nature Geoscience, v. 11, p. 70-76, https://doi.org/10.1038/ s41561-017-0035-y.

ManusCript Received 21 July 2020

REVISED MANUSCRIPT RECEIVED 14 SEPT. 2020

MANUSCRIPT ACCEPTED 17 SEPT. 2020 